\title{
Moraxella nonliquefaciens
}

National Cancer Institute

\section{Source}

National Cancer Institute. Moraxella nonliquefaciens. NCI Thesaurus. Code C86528.

A species of aerobic, Gram neg ative, rod shaped bacteria assigned to the phylum

Proteobacteria. This species is nonmotile, nonhemolytic, oxidase and catalase positive, indole negative and reduces nitrate. M. nonliquefaciens is a commensal organism of the upper respiratory tract but may become pathogenic in immunocompromised individuals. 